\title{
The effect of winter fodder beet or kale allocation on behaviour and blood metabolite status of non-lactating dairy cows
}

\author{
Dawn E. DALLEY ${ }^{1}$, J. Paul EDWARDS ${ }^{1}$, Emma MASTERSON ${ }^{2}$ and Roshean R. WOODS ${ }^{1, *}$ \\ ${ }^{1}$ DairyNZ Ltd, PO Box 85066, Lincoln University, Lincoln 7647, New Zealand \\ ${ }^{2}$ DairyNZ Ltd, Private Bag 3221, Hamilton 3240, New Zealand \\ *Corresponding author: Roshean.Woods@dairynz.co.nz
}

\begin{abstract}
Fodder beet (FB) and kale are commonly used to address winter feed deficits in New Zealand's southern regions. However, the impact of feeding high rates of these crops on metabolic diseases and cow behaviour is uncertain. This study aimed to determine the animal health and wellbeing status of cows fed FB or kale at two allocations by testing blood and activity measures. In winter 2017, 328 mixed-aged, multiparous, pregnant non-lactating Friesian $\mathrm{x}$ Jersey cows were allocated to feeding treatments of either FB or kale, offered at two allocation rates: 'target' (to achieve $0.5 \mathrm{BCS}$ gain) or 'high' (ad libitum) supplemented with pasture baleage. In each treatment, 20 cows had blood metabolites monitored, and 15 cows had an activity sensor fitted for 8 days in early July. Cows fed FB had higher plasma magnesium and lower sodium, phosphate, total protein and urea levels than cows fed kale. Allocation had no effect on blood metabolites. Cows fed FB spent less time lying down $(9.4 v s .11 .1 \mathrm{~h} / \mathrm{d})$, walked more (2113 vs. 1737 steps/d) and had fewer, but longer, lying bouts than those offered kale. Results indicate differences between winter crops in blood indicators of metabolic disease and behaviour which require further investigation.
\end{abstract}

Keywords: wintering, lying time, winter crop

\section{Introduction}

Dairy farming in Southland and Otago has grown in the past 25 years to 862,970 cows on 1427 farms, producing $19 \%$ of New Zealand's total milk solids (LIC \& DairyNZ 2020). Feeding forage crops, for example brassicas and fodder beet (FB), to address winter feed deficits when pasture growth is negligible in the cooler winter months (Nichol et al. 2003), is an important aspect of farming in southern regions.

While use of FB has been rapidly adopted by farmers, there is uncertainty around its impact on metabolic diseases, cow behaviour, hepatic function (Grala et al. 2019) and inflammation status when fed at levels of $70-90 \%$ dry matter (DM) intake, currently used in New Zealand systems. Keogh et al. (2009) reported that pregnant, non-lactating cows grazing FB or kale had higher non esterified fatty acid (NEFA) concentrations than those fed grass silage, which can predispose them to fatty liver disease and altered lipid metabolism during the periparturient period. There is little other published data on the metabolic state of cows grazing winter forage crops and how this might impact on animal health, comfort and welfare.

Activity monitoring is a way of understanding animal wellbeing, for example, time spent lying down is important for animal comfort and welfare, with dairy cows typically lying for $8-10 \mathrm{~h} / \mathrm{d}$ in grazed pasture systems (Schütz et al. 2013). Cows have a strong motivation to lie down and will sacrifice activities, such as feeding, to lie down following periods of restricted lying (Tucker et al. 2021). According to the dairy cattle code of welfare, recommended best practice is that 'under usual conditions cattle should be able to lie and rest comfortably on a dry and well-bedded/ soft surface for 10-12 $\mathrm{h}$ a day to meet their behavioural needs' (Ministry for Primary Industries 2019). Activity monitors, e.g., pedometers, are increasingly used to monitor lying and standing time and lying frequency, to provide information to aid farmer decision making and allow research on cow comfort and welfare, without disturbing natural behavioural expression (Rutten et al. 2013). Lying time can be influenced by the nature of the lying surface, such as wet/muddy conditions, crop type or area per cow. Dalley et al. (2012) reported that, in off-paddock wintering systems, as the area per cow increased, so did lying time. Cows wintered on crops in Southland have been reported to spend an average of $11.2 \mathrm{~h} / \mathrm{d}$ lying down (Stewart et al. 2002) but Dalley et al. (2012) reported a range of lying times (8-12 h/d) between herds and winter crop types, however, the study design did not allow conclusions to be drawn on the reasons for the variability.

The following study measured the animal health and wellbeing status of cows fed FB or kale at two allocations by testing blood parameters and activity measures during winter.

\section{Materials and Methods}

The study was part of a winter-feeding trial conducted between 1 June and 16 October 2017 at the Southern Dairy Hub in Southland, New Zealand $46^{\circ} 18^{\prime} 37.8^{\prime \prime}$, $168^{\circ} 18^{\prime} 46.1$ ”'E, 11 m a.s.l.; (Dalley et al. 2020b). Crops 
compared were a fodder beet (FB; Beta vulgaris L.) and a brassica: kale (Brassica oleracea L.). The soil in the crop paddocks was an Edendale undulating deep soil, with a silty loam texture and well drained. All procedures had prior approval of the Ruakura Animal Ethics Committee, Hamilton, New Zealand (RAEC \#14211).

\section{Animals and experimental design}

There were 328 mixed-aged, multiparous, pregnant non-lactating Friesian $\times$ Jersey cross cows selected for the experiment and randomly allocated to feeding treatments balanced for body condition score (BCS; 10-point scale; Roche et al. 2009), expected calving date, breeding worth (\$BW), production worth (\$PW), cow origin (the herd had recently been established) and age (Dalley et al. 2020b). Calving dates ranged from 20 July 2017 to 16 October 2017. Cows were either fed FB or kale, offered at two different allocation rates, 'target' or 'high'. For the 'target' groups, the ratio of crop to pasture baleage was 70:30 on a DM basis. The energy intake required to achieve an average $\mathrm{BCS}$ gain of 0.7 to meet a target of BCS 5 at calving was calculated using the DairyNZ winter crop allocation calculator, based on the estimated quality and expected utilisation (similar to updated version: DairyNZ 2021). This predicted a consumed metabolisable energy (ME) requirement of $140 \mathrm{MJ} \mathrm{ME} / \mathrm{cow} / \mathrm{d}$. For the 'high' groups, the allocation was at least $80 \%$ crop, offered ad libitum, with the remainder being pasture baleage (approx. 20\%), on a $\mathrm{DM}$ basis. Predicted $\mathrm{ME}$ requirement and $\mathrm{BCS}$ gain for the 'high' allocation were $160 \mathrm{MJ} \mathrm{ME} / \mathrm{cow} / \mathrm{d}$ and 1.25 $\mathrm{BCS}$, respectively.

\section{Transition from pasture to crop and feeding}

Cows were transitioned from pasture onto their respective winter diets from 31 May 2017, and remained on this feed until individual cows were drafted onto pasture and baleage 10 days before their expected calving date. The transition onto FB and kale diets followed good industry practice recommendations provided by Gibbs (2014) and Nichol et al. (2003) to reach their full crop allocations (Table 1). Cows were on their full crop allocations for an average of 55, 62, 74, and 73 days for FB-High, FB-Target, Kale-High, and Kale-Target, respectively, due to the different transition times for each treatment. This is described in further detail by Dalley et al. (2020b).

During transitioning, cows were initially moved on and off the crop each day. At 8 am they received half of their daily pasture and baleage allocation in an adjacent pasture paddock. At 10.30 am they were moved into their respective crop paddocks where they remained until they had either consumed the crop on offer (kale) or reached their time allocation (FB). All cows returned to graze pasture overnight, where they were offered the remainder of their baleage. From day 9, when the diet comprised only crop and baleage, the cows remained on the crop paddock where baleage was offered in ring feeders. The daily crop allocation was offered as a single break at approximately 9 am, except following a frost, when feeding was delayed until it had thawed. Baleage was pre-placed in the paddocks and cows were given access to this at the same time as the crop. Magnesium (as magnesium chloride) was delivered through the inline water dispenser throughout the study period at a rate of $70 \mathrm{~g} / \mathrm{cow} / \mathrm{d}$. No additional mineral supplements were offered to cows while on the crop diets. Once drafted into the springer group, cows were offered $5 \mathrm{~kg} \mathrm{DM} /$ cow $/ \mathrm{d}$ pasture and $5 \mathrm{~kg} \mathrm{DM} /$ cow $/ \mathrm{d}$ baleage. Magnesium oxide $(\mathrm{MgO})$ was dusted onto the new pasture break daily at a rate of $100 \mathrm{~g} \mathrm{MgO} /$ cow/d. Magnesium (MgO; $50 \mathrm{~g} / \mathrm{cow} / \mathrm{d})$ and calcium (limeflour; $100 \mathrm{~g} / \mathrm{cow} / \mathrm{d}$ ) were dusted onto the pasture breaks for the colostrum and milking groups.

Table 1 Allocation and utilisation of fodder beet (FB) or kale fed at two levels (High, Target) to mixed-age pregnant cows during winter (published in Dalley et al. 2020b).

\begin{tabular}{|c|c|c|c|c|}
\hline & FB' ${ }^{1}$-High & FB' ${ }^{1}$ - Target & Kale-High & Kale-Target \\
\hline Crop allocation (kg DM/cow/d) & 11.9 & 9.1 & 14 & 10.5 \\
\hline Utilisation of crop (\%) & 90 & 90 & 80 & 85 \\
\hline Area of crop allocated $\left(\mathrm{m}^{2} / \mathrm{cow} / \mathrm{d}\right)$ & 593 & 398 & 910 & 509 \\
\hline Baleage allocation (kg DM/cow/d) & 3 & 4.5 & 3 & 4.5 \\
\hline Assumed utilisation of baleage (\%) & 85 & 85 & 85 & 85 \\
\hline Dry matter intake (kg DM/cow/d) & 13.3 & 12.0 & 13.8 & 12.8 \\
\hline Metabolizable energy intake (MJ/cow/d) & 176 & 153 & 157 & 147 \\
\hline Nitrogen (g N/cow/d) & 270 & 247 & 331 & 301 \\
\hline
\end{tabular}

${ }^{1}$ Fodder beet mean proportion of bulb was $72 \%$ in Jun, $75 \%$ in Jul, and $82 \%$ in Aug. 


\section{Crop and supplement measurements}

Crop establishment, cultivars of FB and kale and the method for determining the area of the feeding breaks required are described in detail by Dalley et al. (2020b). In brief, FB yields were determined from three $4 \mathrm{~m}$ double rows and kale from three $1 \mathrm{~m}^{2}$ quadrats in the next area to be grazed. Soil was removed from FB and leaf and bulb fresh weights were recorded separately. Kale was cut to ground level and fresh weight recorded. Subsamples of crop and baleage were collected for $\mathrm{DM}$, feed quality and mineral analysis carried out by Hill Laboratories (Hamilton, NZ), results are published in Dalley et al. (2020b).

\section{Blood sampling}

Blood samples were taken between 09:00 and 11:00, before the cows were fed their new crop break, from a pre-determined sub-group of 20 animals from each feeding treatment (sub-group balanced in the same manner as the feeding treatments above) on the day of each blood sampling event listed in Table 2 .

The samples were collected from the coccygeal vein, using evacuated blood tubes containing lithium heparin (BD Vacutainer ${ }^{\circledR}$ Heparin Tube, Becton Dickinson Vacutainer Systems, Franklin Lates, NJ). Blood samples were kept on ice until they could be centrifuged at $3000 \mathrm{rpm}$ for 20 minutes for the extraction of plasma for subsequent analysis by Gribbles Veterinary Pathology Ltd (Hamilton, New Zealand). In brief, blood metabolites were assayed using colourimetric techniques at $37^{\circ} \mathrm{C}$ with a Hitachi Modular P800 analyser (Roche Diagnostics, Indianapolis, IN). Roche reagent kits (Roche Diagnostics, Indianapolis, IN) were used to measure plasma concentrations of phosphate $\left(\mathrm{PO}_{4}\right)$, calcium $(\mathrm{Ca})$, magnesium $(\mathrm{Mg})$, urea, creatinine, total protein, albumin, aspartate aminotransferase (AST), bilirubin, gammaglutamyl transferase (GGT), glutamate dehydrogenase (GDH), and beta-hydroxybutyrate (BOH). Plasma NEFA concentrations were determined using a reagent kit from Wako Chemicals (Osaka, Japan). Globulin was calculated as the difference between total protein and albumin. Potassium $(\mathrm{K})$, sodium $(\mathrm{Na})$, and chloride $(\mathrm{Cl})$ were determined using an ion selective electrode (Roche Diagnostics, Indianapolis, IN).

\section{Behaviour monitoring}

On 4 July 2017, once all cows were fully transitioned onto the crops, 15 cows from each treatment were fitted with a CowAlert IceQube activity sensor (IceRobotics, Edinburgh, Scotland) attached to the hind leg for a 10-day period (sensors removed 13 July 2017). The IceQube sensor is a 3-axis accelerometer that monitors standing time, lying time, lying bouts (number and duration) and step count. Data were captured from the IceQubes in 15-minute intervals and stored on each device. The data were downloaded following removal of the device from the cows. Of the 60 cows with sensors, 46 cows had complete sensor data (FB-High; $\mathrm{n}=12$; FB-Target; $\mathrm{n}=12$; Kale-High; $\mathrm{n}=11$; KaleTarget; $\mathrm{n}=11$ ) and 14 cows were removed from the behaviour analyses due to invalid data (e.g., activity monitor errors or incomplete data). The data recorded on the day that devices were fitted or removed were not included in the analysis. The accuracy of IceQubes has been validated by Borchers et al. (2016) to have a high correlation with visual activity observations. All lying bouts $<33$ seconds were discarded from the raw data to account for erroneous lying bouts as recommended by Kok et al. (2015).

Adverse weather days during behaviour monitoring Daily rainfall and sunshine hours data were retrieved from The National Climate Database (NIWA 2020) for the eight-day behaviour monitoring period (Station agent number $5814 ; 46.3^{\circ} \mathrm{S}, 168.3^{\circ} \mathrm{E}$ ). The distance from the climate station to the study site is $\sim 12 \mathrm{~km}$. There is evidence that both wet and cold conditions can reduce lying behaviour of grazing dairy cows (Hendriks et al. 2019). Therefore, to better understand the influence of weather on behaviour we categorised experimental days into two divergent weather groups which captured all the conditions present. The fairweather days were based on no rainfall $(<1 \mathrm{~mm})$ and sunshine hours $\geq 3.24 \mathrm{~h} / \mathrm{d}$ and the adverse weather days were defined as rainfall $(>1 \mathrm{~mm})$ and sunshine hours $<3.24 \mathrm{~h} / \mathrm{d}$. The threshold for sunshine hours was equal to the mean minus one standard deviation (SD) during the eight days (mean $\pm \mathrm{SD}=5.56 \pm 2.32 \mathrm{~h} / \mathrm{d}$ ).

Table 2 Blood sampling regime for each feeding treatment in the wintering trial.

\begin{tabular}{ll}
\hline Blood sampling events & Feed type being eaten \\
\hline Pre-crop & Cows offered pasture and baleage \\
Established on crop & Fully transitioned onto crop (day 49 on crop) \\
Pre-calving & Between 4- and 17-days pre-calving when cows offered pasture and baleage \\
Day of calving & Cows offered pasture and baleage \\
2 weeks post-calving & Cows grazing pasture \\
\hline
\end{tabular}




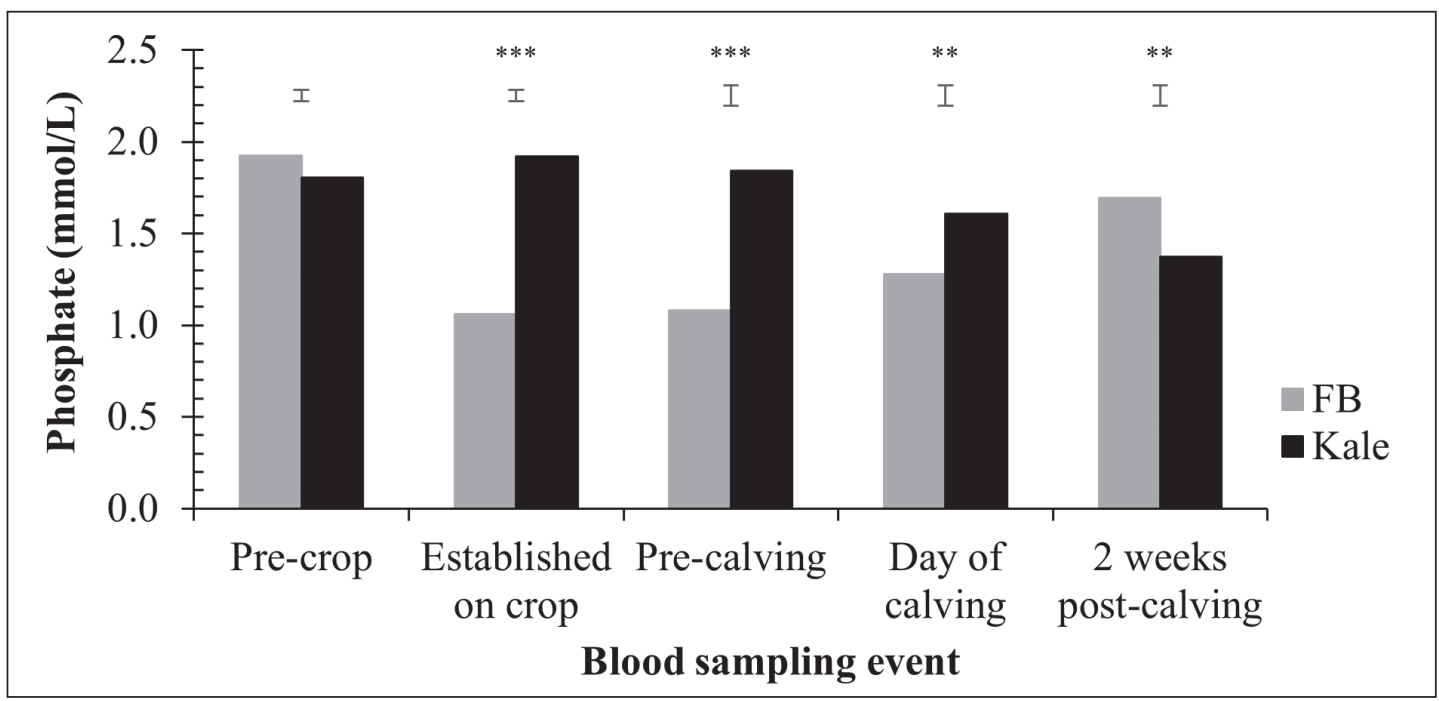

Figure 1 Concentration of phosphate $(\mathrm{mmol} / \mathrm{L})$ in blood plasma of mixed-age cows wintered on fodder beet (FB) and kale. Error bars are 1 standard error of the difference (SED). ${ }^{* \star} P<0.01,{ }^{* \star *} \mathrm{P}<0.001$ show when there is an effect of crop. Reference range for phosphate: 1.4-2.3 mmol/L (Puls 1988).

\section{Statistical analysis}

Statistical analyses were undertaken using SAS 9.4 (SAS Institute Inc., Cary, NC, USA). Results are presented as least-squares means, and standard errors of the differences (SED). The covariance structures selected were autoregressive for blood data and daily behaviour data and autoregressive heterogenous for temporal behaviour data. All repeated measures ANOVA models were pairwise comparison-adjusted using Tukey-Kramer. Bilirubin, GGT, GDH, BOH, AST, and NEFA blood data were log-transformed to achieve homogeneity of variance. Blood data were analysed separately for the crop phase and the calving phase using a mixed models approach to repeated measures analysis of variance (PROC MIXED). The model included crop, time and their interactions as variables of interest, source (where animals came from) and parity group (2, 3 and 4, or 5+) as fixed effects, winter baseline measurement (pre-crop, taken on 30 May 2017) and calving season day (number of days between 1 Jun 2017 and calving) as covariates, and cow as random effect. Significance is declared if $\mathrm{P} \leq 0.05$.

Behaviour data were summarised hourly and daily for each cow. Daily and temporal (hourly) data were analysed using a repeated measures ANOVA (PROC MIXED). Cow was a random effect, with crop, allocation and time (day or hour) and all their interactions as variables of interest and number of days between trial start date and calving, breeding worth, source and parity group as fixed effects. The htype $=1$ option was specified to include the fixed effects sequentially. Lying bout number and duration were log-transformed for analysis and untransformed means and SED presented.
In separate models, associations between daily behaviour data and crop, allocation and weather, including all their interactions, were analysed in the same manner as above. The weather variable (fair vs adverse weather days) was included in place of 'time'. To further investigate differences in lying behaviour between treatments on fair and adverse weather days, the data were summarized for individual cows and days to determine the percentage of cows that spent $<8$ $\mathrm{h} / \mathrm{d}$ lying across the experimental period. Differences in percentage of cows spending $<8 \mathrm{~h} / \mathrm{d}$ lying between treatments were analysed using a Chi-squared test separately for fair and adverse weather days.

\section{Results}

\section{Blood metabolites}

Allocation level did not influence the metabolic profiles, with no significant treatment effects measured, therefore only crop effects are presented. Cows wintered on kale displayed lower levels of $\mathrm{Ca}(\mathrm{P}<0.001), \mathrm{Mg}(\mathrm{P}<0.001)$ and creatinine $(\mathrm{P}<0.001)$ than cows wintered on $\mathrm{FB}$, once established on crop, while $\mathrm{Mg}$ and creatinine remained lower pre-calving (Table 3 ). Fodder beet cows displayed lower $(\mathrm{P}<0.05)$ levels of $\mathrm{Na}, \mathrm{PO}_{4}$, total protein, and urea than cows on kale, once established on crop. When sampled again pre-calving, FB cows continued to show lower levels of $\mathrm{PO}_{4}$ and urea compared with cows on kale $(\mathrm{P}<0.001)$. Phosphate in FB cows continued to be lower compared to kale at calving, but two weeks post calving, once on pasture-based diets, these levels were within the reference range for $\mathrm{PO}_{4}$ (1.4-2.3 $\mathrm{mmol} / \mathrm{L}$, Puls 1988) (Figure 1). Higher BOH levels 


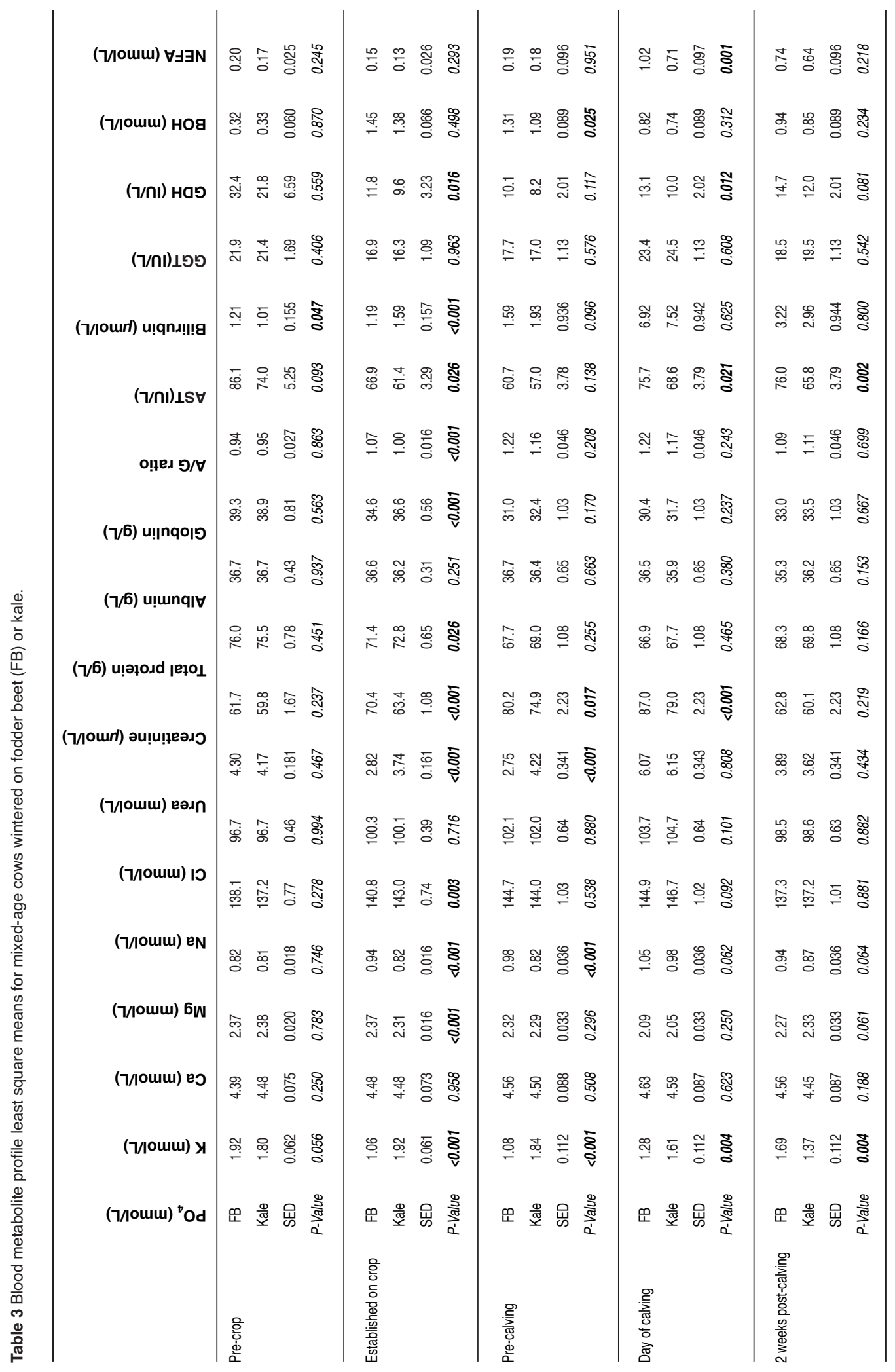


were observed pre-calving for FB cows $(\mathrm{P}=0.025)$, and on the day of calving, FB cows had higher AST, GDH and NEFA levels than kale cows (Table 3).

\section{Behaviour monitoring - weather effects}

Mean rainfall for 'fair weather' days was $0.03 \mathrm{~mm}$ with a range of $0-0.2 \mathrm{~mm}$ and mean sunshine hours were 6.8 $\mathrm{h}$ (5.1-7.9 $\mathrm{h}$ range), whereas for 'adverse weather' these were $8.6 \mathrm{~mm}$ (4.1-13 mm range) and $1.8 \mathrm{~h}(1.3-2.3 \mathrm{~h}$ range), respectively. The adverse weather confounded the behaviour data and therefore to investigate effects of crop and allocation, these data were excluded from the main analysis. However, a comparison between fair weather and adverse weather is made in Table 5.

\section{Behaviour monitoring - fair weather}

The measurement of cow behaviour occurred (precalving) when there were differences in metabolites with the potential to impact animal health, i.e. $\mathrm{PO}_{4}$ and $\mathrm{Mg}$, or there were indications of differences in metabolic stress (BOH concentrations).

Crop had an effect on activity, with cows fed FB lying less $(\mathrm{P}=0.001)$, walking more $(\mathrm{P}<0.001)$ and having fewer but longer lying bouts (6.1 lying bouts/d, 102 $\mathrm{min} /$ bout; $\mathrm{P}<0.001)$ than cows fed kale $(9.3$ bouts $/ \mathrm{d}$, $81 \mathrm{~min} /$ bout; Table 4). There was no overall significant difference in daily lying time between treatments ( $\mathrm{P}=0.206$; Table 4), but cows fed the FB-Target treatment spent less time lying than the other treatments on days 1,3 and $5(\mathrm{P}<0.05$; data not presented).

There were no significant effects of crop $\times$ allocation on hourly behaviour, however, significant crop $\times$ allocation $\times$ time interactions for all behaviours suggest differences throughout the day. Mean lying times were highest between 20:00 and 06:00, and a small bout of lying occurred in the middle of the day between the two major grazing bouts (Figure 2a). Lying times increased sooner after the first grazing bout on kale compared with cows on FB. Correspondingly, cows on FB had a greater number of steps compared with those on kale, especially in the period immediately following the allocation of FB in the morning (Figure 2b).

\section{Behaviour monitoring - adverse weather}

On adverse weather days, less time was spent lying across all treatments, compared with fair weather

Table 4 Mean activity parameters comparing crop and allocation treatments of mixed-age cows wintered on fodder beet (FB) or kale at high and target crop allocations during fair weather conditions. Means with the same letter (a-c) are not significantly different at the $5 \%$ level. SED = standard error of the difference. LB - lying bout.

\begin{tabular}{|c|c|c|c|c|c|c|c|c|c|c|c|}
\hline & \multicolumn{5}{|c|}{ Treatment means } & \multicolumn{3}{|c|}{ Crop means } & \multicolumn{3}{|c|}{ P-values } \\
\hline & $\begin{array}{l}\text { FB- } \\
\text { High }\end{array}$ & $\begin{array}{c}\text { FB- } \\
\text { Target }\end{array}$ & $\begin{array}{l}\text { Kale- } \\
\text { High }\end{array}$ & $\begin{array}{l}\text { Kale- } \\
\text { Target }\end{array}$ & SED & FB & Kale & SED & $\begin{array}{c}\text { Crop } x \\
\text { Allocation }\end{array}$ & Crop & $\begin{array}{l}\text { Alloca- } \\
\text { tion }\end{array}$ \\
\hline Steps & $2015^{\mathrm{ab}}$ & $2273^{a}$ & $1688^{b c}$ & $1546^{c}$ & 148.3 & 2113 & 1737 & 103.8 & 0.065 & $<0.001$ & 0.591 \\
\hline Standing (h) & 12.9 & 14.0 & 11.9 & 11.8 & 0.66 & 14.6 & 12.9 & 0.46 & 0.206 & 0.001 & 0.261 \\
\hline Lying (h) & 11.1 & 10.0 & 12.1 & 12.2 & 0.66 & 9.4 & 11.1 & 0.46 & 0.206 & 0.001 & 0.261 \\
\hline LB Dur (min) & 102 & 111 & 81 & 92 & 7.0 & 102 & 81 & 4.9 & 0.675 & $<0.001$ & 0.099 \\
\hline LB Number & 6.8 & 6.0 & 9.7 & 9.0 & 0.74 & 6.1 & 9.3 & 0.52 & 0.706 & $<0.001$ & 0.052 \\
\hline
\end{tabular}

Table 5 Mean activity parameters comparing crop and allocation treatments of mixed-age cows wintered on fodder beet (FB) or kale at high and target crop allocations in fair vs adverse weather conditions. Means with the same letter (a-c) are not significantly different at the $5 \%$ level. SED $=$ standard error of the difference. LB - lying bout.

\begin{tabular}{|c|c|c|c|c|c|c|c|c|c|c|c|c|}
\hline & \multicolumn{6}{|c|}{ Fair weather } & \multicolumn{6}{|c|}{ Adverse weather } \\
\hline & $\begin{array}{l}\text { FB- } \\
\text { High }\end{array}$ & $\begin{array}{c}\text { FB- } \\
\text { Target }\end{array}$ & $\begin{array}{l}\text { Kale- } \\
\text { High }\end{array}$ & $\begin{array}{l}\text { Kale- } \\
\text { Target }\end{array}$ & SED & $\begin{array}{c}\mathrm{P} \text { - } \\
\text { value }\end{array}$ & $\begin{array}{l}\text { FB- } \\
\text { High }\end{array}$ & $\begin{array}{l}\text { FB- } \\
\text { Target }\end{array}$ & $\begin{array}{l}\text { Kale- } \\
\text { High }\end{array}$ & $\begin{array}{l}\text { Kale- } \\
\text { Target }\end{array}$ & SED & $\begin{array}{c}\text { P. } \\
\text { value }\end{array}$ \\
\hline Steps & $1914^{a}$ & $2222^{a}$ & $1513^{b}$ & $1515^{\mathrm{b}}$ & 141.7 & $<0.001$ & $2049^{b}$ & $1957^{\mathrm{cb}}$ & $2647^{a}$ & $1575^{c}$ & 174.6 & $<0.001$ \\
\hline Standing (h) & $12.7^{\mathrm{ab}}$ & $13.6^{a}$ & $11.6^{\mathrm{b}}$ & $11.5^{\mathrm{b}}$ & 0.62 & 0.003 & $18.6^{a}$ & $18.8^{\mathrm{a}}$ & $14.0^{\mathrm{b}}$ & $18.1^{\mathrm{a}}$ & 0.82 & $<0.001$ \\
\hline Lying (h) & $11.3^{\mathrm{ab}}$ & $10.4^{\mathrm{b}}$ & $12.4^{\mathrm{a}}$ & $12.5^{\mathrm{a}}$ & 0.62 & 0.003 & $5.4^{\mathrm{b}}$ & $5.2^{\mathrm{b}}$ & $10.0^{\mathrm{a}}$ & $5.9^{\mathrm{b}}$ & 0.82 & $<0.001$ \\
\hline LB Dur (min) & $100^{\mathrm{ab}}$ & $112^{\mathrm{a}}$ & $80^{\mathrm{b}}$ & $89^{a b}$ & 7.6 & 0.004 & $83^{a b}$ & $106^{\mathrm{a}}$ & $63^{b}$ & $78.9^{\mathrm{b}}$ & 11.6 & 0.01 \\
\hline LB Number & $7.2^{\mathrm{b}}$ & $6.1^{\mathrm{b}}$ & $10.4^{\mathrm{a}}$ & $9.9^{\mathrm{a}}$ & 0.79 & $<0.001$ & $5.1^{b}$ & $3.5^{b}$ & $9.9^{\mathrm{a}}$ & $6.1^{b}$ & 1.07 & $<0.001$ \\
\hline $\begin{array}{l}\% \text { of cows } \\
<8 \text { h/d lying }\end{array}$ & 12.5 & 23.6 & 0.0 & 0.0 & & $<0.001$ & 87.5 & 83.3 & 13.6 & 77.3 & & $<0.001$ \\
\hline
\end{tabular}




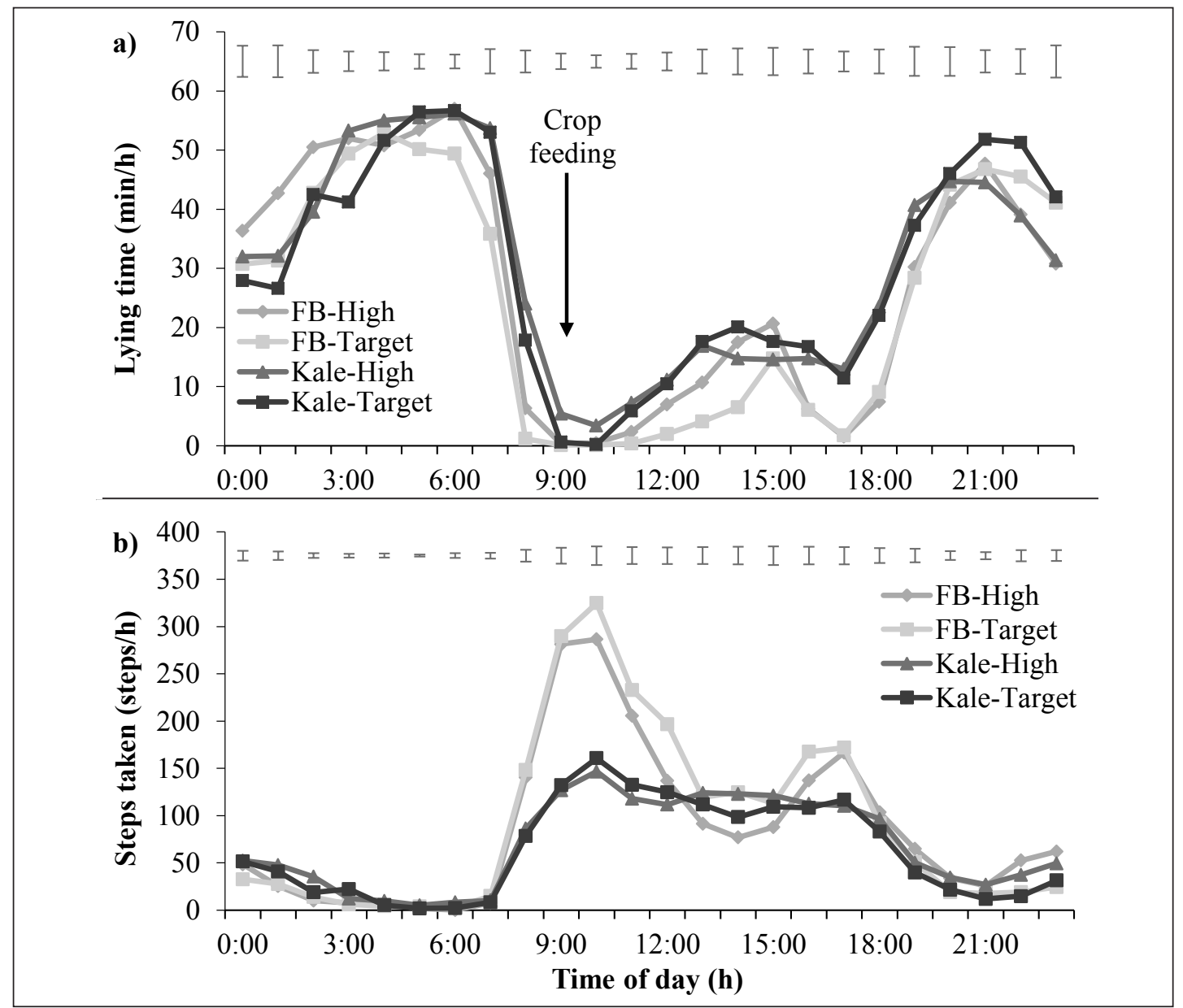

Figure 2 Mean a) lying time $(\mathrm{min} / \mathrm{h})$ and b) steps taken $(\mathrm{steps} / \mathrm{h})$ for each treatment compared over a day for mixed-age cows wintered on fodder beet (FB) or kale at high and target allocations for a six-day period in fair weather conditions. Error bars are 1 standard error of the difference (SED).

days (Table 5). There were more steps (except for FB-Target), fewer lying bouts, and shorter total lying bout durations during the adverse weather days. A Chi-squared test showed a significant difference in the percentage of cows lying for $<8 \mathrm{~h} / \mathrm{d}$ between treatments $(\mathrm{P}<0.001)$. Numerically, a greater percentage of FB cows lay for $<8 \mathrm{~h} / \mathrm{d}$ under fair weather conditions, than kale cows. Under adverse weather conditions, a greater percentage of cows lay down for $<8 \mathrm{~h} / \mathrm{d}$ in both FB and the Kale-Target treatments. Overall, under adverse weather conditions, the Kale-High treatment had a higher mean lying time (of $10.0 \mathrm{~h}$ ) compared with the other treatments (5.2-5.9 h).

\section{Discussion}

\section{Blood metabolites}

Blood mineral status has implications for mineral supplementation of cows consuming crops, especially fodder beet which is known to have low P levels in the bulb (Gibbs et al. 2015). Phosphorus (P) deficiency increases the risk of metabolic disorders at calving (Goff 2018). In this experiment cows grazing FB had blood $\mathrm{PO}_{4}$ levels, when grazing $\mathrm{FB}$, pre-calving and on the day of calving, below the reference range (1.4-2.3 $\mathrm{mmol} / \mathrm{L}$, Puls 1988) and below recommended levels for late pregnancy (Dalley et al. 2020b). These blood results reflect the low $\mathrm{P}$ content of the FB bulb and the lack of $\mathrm{P}$ supplementation in this study. In comparison, cows wintered on kale had plasma $\mathrm{PO}_{4}$ levels within the reference range. While blood $\mathrm{PO}_{4}$ does not reflect the full $\mathrm{P}$ status of the cows, the decline in concentrations with time on crop indicates that the cows were not able to maintain blood $\mathrm{PO}_{4}$ levels through mobilisation of bone reserves. To reduce the risk of $\mathrm{P}$ deficiency at calving and to ensure bone mineral levels are replete for calving, farmers should be providing $\mathrm{P}$ 
supplementation when feeding FB to ensure minimum dietary requirements are being met.

The lower levels of $\mathrm{Mg}$ shown for cows wintered on kale and pre-calving was unexpected because there were no differences in the $\mathrm{Mg}$ content of the diet (Dalley et al. 2020b). However, the intake of increased amounts of soluble carbohydrates from FB bulb may lower ruminal $\mathrm{pH}$ through an increased production rate of lactic acid and volatile fatty acids (Darwin et al. 2018). A decrease in $\mathrm{pH}$ may raise the solubility of $\mathrm{Mg}$ (Dalley et al. 1997), which in turn could enhance the availability of $\mathrm{Mg}$ for absorption across the ruminal epithelium.

The lower plasma $\mathrm{Ca}$ for cows wintered on kale, compared with $\mathrm{FB}$, was unexpected because the kale diets had a much higher Ca content (Dalley et al. 2020b). A possible explanation is that low $\mathrm{P}$ diets during the non-lactating period (as seen in the FB treatments in the current study) can increase plasma $\mathrm{Ca}$ and thus may help prevent hypocalcaemia during the first week postpartum (Keanthao et al. 2021). Mean plasma $\mathrm{Mg}$ and $\mathrm{Ca}$ levels for both $\mathrm{FB}$ and kale cows were within expected ranges reported by Puls (1988) of 2-2.7 mmol/L for $\mathrm{Ca}$ and $0.74-1.4 \mathrm{mmol} / \mathrm{L}$ for $\mathrm{Mg}$, although some individual cows did show levels below these ranges.

Dietary protein levels for both crop diets were above the recommended $12 \%$ for non-lactating dairy cows (DairyNZ 2020) with dietary CP concentrations of $12.6 \%$ and $13.0 \%, 14.9 \%$ and $14.6 \%$ for FB-High, FB-Target, Kale-High and Kale-Target, respectively (Dalley et al. 2020b). However, there was a trend for $\mathrm{N}$ intake to be lower for FB diets (Dalley et al. 2020b). This is reflected by the lower plasma urea levels while grazing the crop and pre-calving for cows fed FB compared with kale in the current study, although these were within the recommended reference range of 2.6$8 \mathrm{mmol} / \mathrm{L}$ (Payne \& Payne 1987). Lower plasma urea and lower urinary-N concentrations with increasing FB content in the diet have been observed (Dalley et al. 2020a) and this could have environmental benefits by reducing $\mathrm{N}$ leaching.

Interestingly, mean plasma $\mathrm{BOH}$ levels for both $\mathrm{FB}$ and Kale cows were $>1.2 \mathrm{mmol} / \mathrm{L}$ once at full crop allocation, which suggests a risk of hyperketenomia (McArt et al. 2013). Given the ME intakes that were being offered and the lack of metabolic disease we have no explanation for these results. Following the removal of cows from crop pre-calving the $\mathrm{BOH}$ levels remained high $(>1.2 \mathrm{mmol} / \mathrm{L})$ for $\mathrm{FB}$ cows but returned to normal levels for kale cows $(<1.2 \mathrm{mmol} / \mathrm{L}$; Table $3)$. In this study FB cows had a number of elevated blood metabolites pre-calving or at calving, indicative of metabolic disease (BOH, AST, GDH, NEFA), but these did not result in increased incidence of clinical disease.

\section{Behaviour monitoring - fair weather}

The fewer but longer lying bouts of cows wintered on $\mathrm{FB}$, compared with kale, could imply that there were more comfortable lying spots available in the kale paddocks in the current study. Greater lying bout duration and reduced frequency have been reported to suggest a lack of comfort or even difficulty standing up and lying down (Haley et al. 2001). Therefore, it is possible that in the FB paddocks when the cows had the opportunity to utilise a comfortable area they lay for longer. Average lying times being highest between 20:00 and 06:00 in the current study is consistent with literature that states ruminating and resting tends to occur at night, and peaks of grazing activity are associated with sunrise and sunset (Kilgour 2012).

The greater number of steps for cows wintered on FB compared with kale could be explained by higher intake rates of kale initially after daily allocation of crop. Thompson and Stevens (2012) showed higher intake rates of kale 3 and $5 \mathrm{~h}$ after being fed, compared with swedes, where cows consumed $92 \%$ of their kale allocation within the first $3 \mathrm{~h}$ (this was $65 \%$ for swedes). They hypothesised this may reflect the ease of harvest for each crop: kale being upright with all its palatable biomass above ground, compared with swedes as a root crop where a high proportion of the DM is in the soil making consumption of this portion slower. The FB crops in the current study were comparable to swedes in this regard, both being bulb crops. Therefore, more time spent harvesting and foraging for food rather than lying and ruminating could have increased the FB cows' number of steps.

All treatments averaged $>8 \mathrm{~h} / \mathrm{d}$ of lying during 'fair weather'. The lower average lying time of the FBTarget cows on some days (data not presented) could have resulted from the smaller area per cow available (Table 1) and, therefore, increased stocking density could create muddier conditions in the paddock.

\section{Behaviour monitoring - effects of adverse weather}

Cows are less likely to lie in wet and muddy conditions, and such adverse conditions have negative implications for their welfare (Chen et al. 2017). Exposure to wind and rain results in prolonged periods of standing (Tucker et al. 2007). This was shown in the current study where average lying time was much less for all treatments on the 'adverse weather' days, except for the Kale-High treatment. The location of the paddock these cows were grazing, and the direction of grazing resulted in the kale crop for Kale-High providing shelter from the prevailing wind. For the other three treatments there was no protection from the prevailing weather. Although the behaviour data in this study were measured over a short period, they provide interesting initial observations which should be investigated further. 


\section{Conclusion}

Both blood metabolite and animal behaviour data indicate that winter crop type (FB vs kale) affected indicators of animal wellbeing. Fodder beet cows had lower plasma $\mathrm{PO}_{4}$ levels while on crop, pre-calving and at calving, and spent less time lying, than kale cows. The results suggest differences between crops in the susceptibility of cows grazing these to metabolic disease but a longer-term study is required to fully test this hypothesis. Differences in animal behaviour between crops requires further investigation. The KaleHigh treatment indicated the possibility to utilise the kale crop as shelter to maintain lying times during adverse weather conditions.

\section{ACKNOWLEDGEMENTS}

This project was funded by the dairy farmers of New Zealand through DairyNZ Inc. (Hamilton, New Zealand), contract RDN1805. We would like to thank W. Ritchie and N. S. Hammond for managing data collection, the farm team at the Southern Dairy Hub for animal management, and B. Kuhn-Sherlock and S. Hendriks for statistical analysis.

\section{REFERENCES}

Borchers M, Chang Y, Tsai I, Wadsworth B, Bewley J. 2016. A validation of technologies monitoring dairy cow feeding, ruminating, and lying behaviors. Journal of Dairy Science 99: 7458-7466. https://doi. org/10.3168/jds.2015-10843

Chen JM, Stull CL, Ledgerwood DN, Tucker CB. 2017. Muddy conditions reduce hygiene and lying time in dairy cattle and increase time spent on concrete. Journal of Dairy Science 100: 2090-2103. https:// doi.org/10.3168/jds.2016-11972

DairyNZ. 2020. Facts and Figures: a quick reference guide for New Zealand dairy farmers. DNZ30-001 https://www.dairynz.co.nz/media/5794071/factsand-figures-updated-2020.pdf.

DairyNZ. 2021. Winter crop allocation calculator. Retrieved 1 Oct 2021 from: https://www.dairynz. co.nz/media/5793877/winter-crop-pastureallocation-calculator-2020.xlsm.

Dalley D, Waugh D, Griffin A, Higham C, de Ruiter J, Malcolm B. 2020a. Productivity and environmental implications of fodder beet and maize silage as supplements to pasture for late lactation dairy cows. New Zealand Journal of Agricultural Research 63: 145-164. https://doi.org/10.1080/00288233.2019.16 75717

Dalley DE, Isherwood P, Sykes AR, Robson AB. 1997. Effect of in vitro manipulation of $\mathrm{pH}$ on magnesium solubility in ruminal and caecal digesta in sheep. The Journal of Agricultural Science 129: 107-111. https://doi.org/10.1017/S0021859697004486
Dalley DE, Verkerk GA, Geddes T, Irwin A, Garnett E. 2012. Impact of wintering system in the southern South Island of New Zealand on the lying behaviour of dairy cows. Presented at: Australasian Dairy Science Symposium. Melbourne, Australia. Pp. 252-254.

Dalley DE, Edwards JP, Woods RR. 2020b. Impact of winter fodder beet or kale allocation on body condition score gain and early lactation performance of dairy cows. Journal of New Zealand Grasslands 82: 73-81. https://doi.org/10.33584/jnzg.2020.82.452

Darwin, Barnes A, Cord-Ruwisch R. 2018. In vitro rumen fermentation of soluble and non-soluble polymeric carbohydrates in relation to ruminal acidosis. Annals of Microbiology 68: 1-8. https://doi. org/10.1007/s13213-017-1307-x

Gibbs J. 2014. Fodder beet in the New Zealand dairy industry. Presented at: South Island Dairy Event (SIDE). Invercargill, New Zealand. Pp. 237-246.

Gibbs J, Saldias B, Trotter C. 2015. Feeding fodder beet in lactation and to replacement heifers. Presented at: South Island Dairy Event (SIDE). Lincoln, New Zealand. Pp. 22-24.

Goff JP. 2018. Invited review: Mineral absorption mechanisms, mineral interactions that affect acidbase and antioxidant status, and diet considerations to improve mineral status. Journal of Dairy Science 101: 2763-2813. https://doi.org/10.3168/jds.201713112

Grala TM, Handley RR, Phyn CVC, Roche JR, Dalley DE. 2019. A quantitative case study assessment of changes to hepatic metabolism from nonlactating grazing dairy cows consuming a large proportion of their diet as fodder beet. Journal of Dairy Science 102: 8559-8570. https://doi.org/10.3168/jds.201816009

Haley DB, de Passillé AM, Rushen J. 2001. Assessing cow comfort: effects of two floor types and two tie stall designs on the behaviour of lactating dairy cows. Applied Animal Behaviour Science 71: 105-117. https://doi.org/10.1016/S0168-1591(00)00175-1

Hendriks S, Phyn C, Turner S-A, Mueller K, Roche J, Kuhn-Sherlock B, Donaghy D, Huzzey J. 2019. Effect of weather on activity and lying behaviour in clinically healthy grazing dairy cows during the transition period. Animal Production Science 60: 148-153. https://doi.org/10.1071/AN18569

Keanthao P, Goselink RMA, Dijkstra J, Bannink A, Schonewille JT. 2021. Effects of dietary phosphorus concentration during the transition period on plasma calcium concentrations, feed intake, and milk production in dairy cows. Journal of Dairy Science. https://doi.org/10.3168/jds.2021-20488

Keogh B, French P, McGrath T, Storey T, Mulligan FJ. 2009. Effect of three forages and two forage allowances offered to pregnant dry dairy cows in 
winter on periparturient performance and milk yield in early lactation. Grass and Forage Science 64: 292-303. https://doi.org/10.1111/j.13652494.2009.00697.x

Kilgour RJ. 2012. In pursuit of "normal": A review of the behaviour of cattle at pasture. Applied Animal Behaviour Science 138: 1-11. https://doi. org/10.1016/j.applanim.2011.12.002

Kok A, van Knegsel ATM, van Middelaar CE, Hogeveen H, Kemp B, de Boer IJM. 2015. Technical note: Validation of sensor-recorded lying bouts in lactating dairy cows using a 2-sensor approach. Journal of Dairy Science 98: 7911-7916. https://doi. org/10.3168/jds.2015-9554

LIC, DairyNZ. 2020. New Zealand Dairy Statistics 2019-20. Retrieved 29 September 2021 from: https://www.lic.co.nz/documents/892/NZ_Dairy_ Statistics_2019-20_WEB_FINAL.pdf.

McArt JAA, Nydam DV, Oetzel GR. 2013. Dry period and parturient predictors of early lactation hyperketonemia in dairy cattle. Journal of Dairy Science 96: 198-209. https://doi.org/10.3168/ jds.2012-5681

Ministry for Primary Industries. 2019. Code of Welfare: Dairy Cattle. Retrieved 24 September 2021 from: https://www.mpi.govt.nz/dmsdocument/46024Code-of-Welfare-Dairy-cattle.

National Institute of Water and Atmospheric Research (NIWA). 2020. The National Climate Database. Retrieved 8 May 2020 from: https://cliflo.niwa. co.nz/.

Nichol W, Westwood C, Dumbleton A, Amyes J. 2003. Brassica wintering for dairy cows: overcoming the challenges. Presented at: South Island Dairy Event (SIDE). Canterbury, New Zealand. Pp. 154-172.

Payne JM, Payne S. 1987. The metabolic profile test: Oxford University Press,

Puls R. 1988. Mineral Levels in Animal Health:
Diagnostic Data: Sherpa International,

Roche JR, Friggens NC, Kay JK, Fisher MW, Stafford KJ, Berry DP. 2009. Invited review: Body condition score and its association with dairy cow productivity, health, and welfare. Journal of Dairy Science 92: 5769-5801. https://doi.org/10.3168/jds.2009-2431

Rutten CJ, Velthuis AGJ, Steeneveld W, Hogeveen H. 2013. Invited review: Sensors to support health management on dairy farms. Journal of Dairy Science 96: 1928-1952. https://doi.org/10.3168/ jds.2012-6107

Schütz KE, Cox NR, Macdonald KA, Roche JR, Verkerk GA, Rogers AR, Tucker CB, Matthews LR, Meier S, Webster JR. 2013. Behavioral and physiological effects of a short-term feed restriction in lactating dairy cattle with different body condition scores at calving. Journal of Dairy Science 96: 44654476. https://doi.org/10.3168/jds.2012-6507

Stewart M, Fisher A, Verkerk G, Matthews L. 2002. Winter dairy grazing systems: management practices and cow comfort. Presented at: Proceedings of the New Zealand Society of Animal Production. Palmerston North, New Zealand. Pp. 44-48.

Thompson BR, Stevens DR. 2012. A comparison of the intake of cows grazing swedes and kale and consequent condition score change. Proceedings of the New Zealand Grassland Association 74: 63-68. https://doi.org/10.33584/jnzg.2012.74.2895

Tucker CB, Rogers AR, Verkerk GA, Kendall PE, Webster JR, Matthews LR. 2007. Effects of shelter and body condition on the behaviour and physiology of dairy cattle in winter. Applied Animal Behaviour Science 105: 1-13. https://doi.org/10.1016/j. applanim.2006.06.009

Tucker CB, Jensen MB, de Passillé AM, Hänninen L, Rushen J. 2021. Invited review: Lying time and the welfare of dairy cows. Journal of Dairy Science 104: 20-46. https://doi.org/10.3168/jds.2019-18074 